\title{
Characteristics of Journal Authorship by Academic Librarians
}

\author{
John M. Budd and Charles A. Seavey
}

A widely held belief that academic librarians are strongly encouraged to publish in order to retain employment may exist. The present study examines authorship in thirty-six library and information science journals over a five-year period and finds that a small proportion of fouryear institutions is responsible for formal contributions to the literature. Furthermore, of those individuals contributing to the literature, the vast majority make only one contribution in the five-year period.

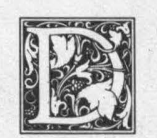

ozens of articles have been written on faculty status. Still, it is an issue that, in one permutation or another, continues to be a part of the lives of academic librarians. Institutions and individuals have formulated arguments designed to praise certain structures and/or damn others. Emily Werrell and Laura Sullivan recently published a review of literature on the subject that has appeared since 1974, and Kee DeBoer and Wendy Culotta surveyed the literature on the subject written in the 1980s; their work need not be repeated in detail here. ${ }^{1,2}$ One of the most intriguing features of the issue is the multifaceted nature of the beast. Faculty (or its confrere, academic) status encompasses such aspects of academic librarianship as governance, bargaining, salary, performance review, and time management. A key component of faculty status is frequently that of publishing requirements and activity. This component is the basis of the present study.

One question that arises relates to the extensiveness of the requirement to publish in academic libraries. Is publication essential to tenure or continuing appoint- ment? While there may be a widely held belief that working in any academic library means that one has to publish, there is evidence to the contrary. The results of this investigation tend to reenforce that evidence. Ronald Rayman and Frank Goudy sought an answer to this question in 1980. They surveyed ARL libraries, and of the 68 respondents, only ten (15 percent) stated that publication was required. ${ }^{3}$ Another 41 , or 60 percent, acknowledged that publication was encouraged, though not required. By combining the required and encouraged categories, Rayman and Goudy's data suggest that publication is necessary in 75 percent of the ARL libraries. One factor, noted by Rayman and Goudy, that may well affect the number of publications emanating from academic libraries is the fact that 33 of the responding libraries (49 percent) offer no release time to librarians for research and publishing activities. ${ }^{4}$ Payne and Wagner replicated the study of Rayman and Goudy, using ACRL university libraries as the population. They found that only three of 43 responding libraries require publication for tenure and/or promotion. ${ }^{5}$ Twenty libraries ( 54 percent of respondents) offer no release time.

John M. Budd and Charles A. Seavey are faculty at the Graduate Library School of the University of Arizona, Tucson, AZ 85719. 
In 1985 W. Bede Mitchell and L. Stanislava Swieszkowski surveyed full and associate members of the Center for Research Libraries. Of the 138 respondents, 81 stated that they grant some form of tenure and, of those 81,38 (46.9 percent) require evidence of research and publication for tenure. ${ }^{6}$ Only half of the libraries requiring publication make release time available to librarians.

\section{"The journals selected for this study are national in scope and are likely to be looked upon favorably in promo- tion and tenure reviews."}

In spite of the fact that release time for research and publication is not abundant and that librarians report that they have little time to devote to the activity, many contributions are made to library literature each year by academic librarians. ${ }^{7}$ The purpose of the present study is to examine the publishing activity of this group. Other efforts at this kind of analysis have been made in the recent past; this paper is intended to be an extension of and expansion upon those studies. ${ }^{8}$ Focus here will be exclusively on authors in the library literature who are academic librarians. In addition, we will analyze the institutional affiliations of those authors to see what patterns emerge.

\section{METHODOLOGY}

Previous studies aimed at analyzing patterns and characteristics of authorship by academic librarians have focused on limited numbers of journals. Sylvia Krausse and Janice Sieburth selected twelve journals; Paula Watson chose eleven. ${ }^{9,10}$ While the journals selected by those researchers include titles of special interest to academic librarians, such as College E Research Libraries and Journal of Academic Librarianship, other journals in the field address issues pertinent to the work of academic libraries. For this reason, thirty-six journals are included in the present study; these are listed in appendix A. The journals selected are national in scope, contain some portion of their content that is judged relevant to the academic enterprise, and are likely to be looked upon favorably in promotion and tenure reviews. In fact, sixteen of the journals included here are also on the list of thirty-one titles in the ranking study of David Kohl and Charles Davis, which seeks to determine in which journals library educators and academic library directors think librarians should publish. ${ }^{11}$ Not all of the thirty-six journals are refereed, but such titles as Library Trends are important to the field and are included.

The time period selected for study was the five-year period 1983-87. Each issue of the journals listed was inspected. Only full-length articles appearing in the target journals are included in the study; notes, editorials, book reviews, columns, and responses are excluded. For each article, the author's name is recorded, as is the author's institutional affiliation. Total credit for authorship of each article equals one (1); for multi-authored articles credit is assigned fractionally to each author, according to the practice of Watson. ${ }^{12}$ If there are two authors, each receives .5 credit, for three each receives .33 , and so on. Institutional credit is likewise assigned. Institutional affiliation is taken from the article itself or from information on contributors to the journal issue. Credit is given on the basis of the author's affiliation at the time the article was published.

\section{FINDINGS}

A total of 1,656 articles written by academic librarians from 1983 through 1987 provide the basis for examination. It is recognized that academic librarians may not compose a majority of contributors to the library literature. In 1982, Krausse and Sieburth found that academic librarians had authorial responsibility for 42.3 percent of the articles in the twelve journals they analyzed. ${ }^{13}$ Watson found that, for the period 1979 through 1983, academic librarians wrote 44.2 percent of the articles in eleven journals. ${ }^{14}$ She also found that the next largest group of authors was library school faculty and students, so academic librarians formed a majority group among practitioners. This holds only for the eleven 
journals she studied; inclusion of journals in other specialized areas, such as Public Libraries, would alter the percentages.

The 1,656 articles were written by 1,373 different individuals. As can be expected, the vast majority of individuals were responsible, in full or in part, for only one contribution each. In fact, 1,027 librarians had their names attached to only one article. Only 128 individuals were identified as sole or coauthors of more than two articles each. The most prolific authorsthose with total credit of four or more (including full and fractional credit)-are listed in table 1.

As is noted above, a relatively small number of individuals are responsible for multiple contributions. A question that arises with regard to this group of data is whether or not it conforms to Alfred Lotka's law, which states that "the number (of authors) making $n$ contributions is about $1 / \mathrm{n}^{2}$ of those making one; and the proportion of all contributors, that make a single contribution, is about 60 percent. ${ }^{\prime \prime}$ Lotka's computation included derivation of the percentage of the total number of contributors making $\mathrm{n}$ contributions. The formula to determine the percentage (f) is

$$
f=600 / \pi^{2} n^{2}
$$

The signification $\mathrm{Fo}(\mathrm{X})$ can represent the cumulative value of $f$. In order to make comparisons it is necessary to calculate observed percentages and the cumulative value of the percentages expressed as $\mathrm{S} \xi(\mathrm{X})$.

Lotka's original work was based on analysis of author data from Chemical $A b$ stracts. From his observations he formulated the above statement. This phenomenon, which has come to be referred to as Lotka's law, is not intended as an explanation of why some authors are more prolific than others. Because of varying modes of behavior, patterns of productivity will differ among disciplines. For instance, the average faculty members in physics will be responsible for more journal articles than the average faculty member in English. Within a given discipline there will be variance also, due in part to differences of motivation and demand. These two variables may be related; those individ- uals who are motivated to write and publish likely gravitate to institutions where such activity is expected and valued.

It remains to be seen whether the verbal expression of Lotka's law exhibits statistical regularity. Russel Coile demonstrates that the Kolmogorov-Smirnov (K-S) test, a nonparametric goodness-of-fit test, is the appropriate measure of the conformity of observed theoretical data. ${ }^{16}$ This test is used to determine how well the actual patterns of authorship match the predictions of Lotka. The K-S statistic at the .01 level of significance, which is equal to $1.63 / \mathrm{N}$, must be greater than the maximum deviation of $S \xi(X)$ and $F_{o}(X)$ (expressed as $D=$ $\max |\mathrm{Fo}(\mathrm{X})-\mathrm{S} \xi(\mathrm{X})|$ ) for such conformity to exist. Table 2 presents the authorship data in terms of Lotka's law.

As can be seen from table 2, the authorship data used for this study do not conform to Lotka's law. The deviation from the expected values is quite severe; while

\section{TABLE 1}

\section{MOST PRODUCTIVE INDIVIDUALS}

\begin{tabular}{rlc}
\hline \hline Rank & Name & Total Credit \\
\hline 1 & Studwell, William & 9.33 \\
2 & Stankus, Tony & 9.0 \\
3 & Connolly, Bruce & 6.5 \\
4 & Gorman, Michael & 6.0 \\
4 & Stevens, Norman & 6.0 \\
6 & Bailey, Bill & 5.0 \\
6 & Burger, Robert H. & 5.0 \\
6 & Cruse, Larry & 5.0 \\
6 & DeGennaro, Richard & 5.0 \\
6 & Dougherty, Richard M. & 5.0 \\
6 & Martin, Susan K. & 5.0 \\
6 & Morton, Bruce & 5.0 \\
6 & Tuttle, Marcia & 5.0 \\
14 & Mendelsohn, Henry N. & 4.5 \\
14 & Pankake, Marcia & 4.5 \\
14 & Zink, Steven D. & 4.5 \\
17 & Atkinson, Hugh & 4.0 \\
17 & Crotts, Joe & 4.0 \\
17 & Goehner, Donna M. & 4.0 \\
17 & Hewitt, Joe A. & 4.0 \\
17 & Hilker, Emerson & 4.0 \\
17 & Isaacson, David & 4.0 \\
17 & McBride, Ruth B. & 4.0 \\
17 & McCrank, Lawrence J. & 4.0 \\
17 & Meyer, Evelyn S. & 4.0 \\
17 & Rutledge, John & 4.0 \\
17 & Schmidt, Karen A. & 4.0 \\
17 & Sewell, Robert G. & 4.0 \\
17 & Smith, Frederick E. & 4.0 \\
17 & Swan, John & 4.0 \\
17 & Watson, Paula D. & 4.0 \\
17 & Williams, James W. & 4.0 \\
\hline & & \\
& & M. \\
\hline
\end{tabular}


TABLE 2

APPLICATION OF LOTKA'S LAW

\begin{tabular}{rccccc}
\hline \hline No. & Observed & $S \xi(X)$ & Expected & Fo $(X)$ & $|F o(X)-S \xi(X)|$ \\
\hline Cont. & 0.7480 & 0.7480 & 0.6079 & 0.6079 & 0.1401 \\
1 & 0.1588 & 0.9068 & 0.1520 & 0.7599 & 0.1469 \\
2 & 0.0510 & 0.9578 & 0.0675 & 0.8274 & 0.1304 \\
3 & 0.0248 & 0.9826 & 0.0380 & 0.8654 & 0.1172 \\
4 & 0.0109 & 0.9935 & 0.0243 & 0.8897 & 0.1038 \\
5 & 0.0036 & 0.9971 & 0.0169 & 0.9066 & 0.0905 \\
6 & 0.0015 & 0.9986 & 0.0124 & 0.9160 & 0.0826 \\
7 & 0.0000 & 0.9986 & 0.0095 & 0.9285 & 0.0701 \\
8 & 0.0000 & 0.9986 & 0.0075 & 0.9360 & 0.0626 \\
9 & 0.0007 & 0.9993 & 0.0061 & 0.9421 & 0.0572 \\
10 & & & & \\
\hline
\end{tabular}

$\mathrm{D}=\operatorname{Max}|\mathrm{Fo}(\mathrm{X})-\mathrm{S} \xi(\mathrm{X})|=0.1469$.

At .01 level of significance, K-S statistic $=1.63 / 1373=0.0440$

D $>0.0440$; this does not fit Lotka's Law.

Lotka observed and formulated a decline in author productivity, the decline among academic librarians is steeper than Lotka anticipated. The steepness of the decline is evident in figure 1 . The shapes of the curves are very similar, but the cluster of individuals at one contribution is substantially larger than the theory anticipates.

\section{"While publication is required or en- couraged at a number of institutions, the encouragement in terms of tangi- ble assistance, such as release time, is not sufficient to produce multiple contributions by librarians."}

Speculation regarding this set of data can lead to some conclusions: while publication is required or encouraged at a number of institutions, the encouragement (in terms of tangible assistance, such as release time) is not sufficient to produce multiple contributions by librarians; or, the number of institutions neither requiring nor encouraging publication results in little motivation to contribute to the literature. This is, however, speculation; more information regarding specific publication requirements, including definition of what constitutes publication, may shed more light on this aspect of the issue.

The 1,373 individuals in the population are affiliated with 384 different institutions. As is true with authors, some insti- tutions are responsible for multiple contributions. One hundred thirty-four institutions appear only once each. The twenty most productive libraries are presented in table 3. Per capita contributions are based on the total professional library staff for 1985-86. It is possible, although unlikely, that the number of librarians would change enough over the five-year period to greatly affect these figures. Of the twenty institutions, eighteen are currently members of the Association of Research Libraries (one, the University of Illinois-Chicago, recently became a member). The other two are included among ACRL university libraries. That these larger libraries are the most productive is not surprising. These libraries have the benefit of numbers; their staff sizes are considerable. They also have broader and deeper resources-bigger collections, a research impetus on the campus at large, and large faculties that may be used as sources of information and expertise.

A very brief questionnaire was mailed to the directors of the twenty most productive libraries and to a sample of other libraries represented by at least one contribution. Since the purpose of the sample is essentially to identify the occurrence of a publishing requirement, the following formula for the determination of sample size is used: ${ }^{17}$

$$
\mathrm{n}=\frac{(\mathrm{Z} \alpha+\mathrm{Z} \beta)^{2} \sigma^{2} \Delta}{\delta^{2}}
$$

This formula is designed to limit the prob- 
Lotka Comparison

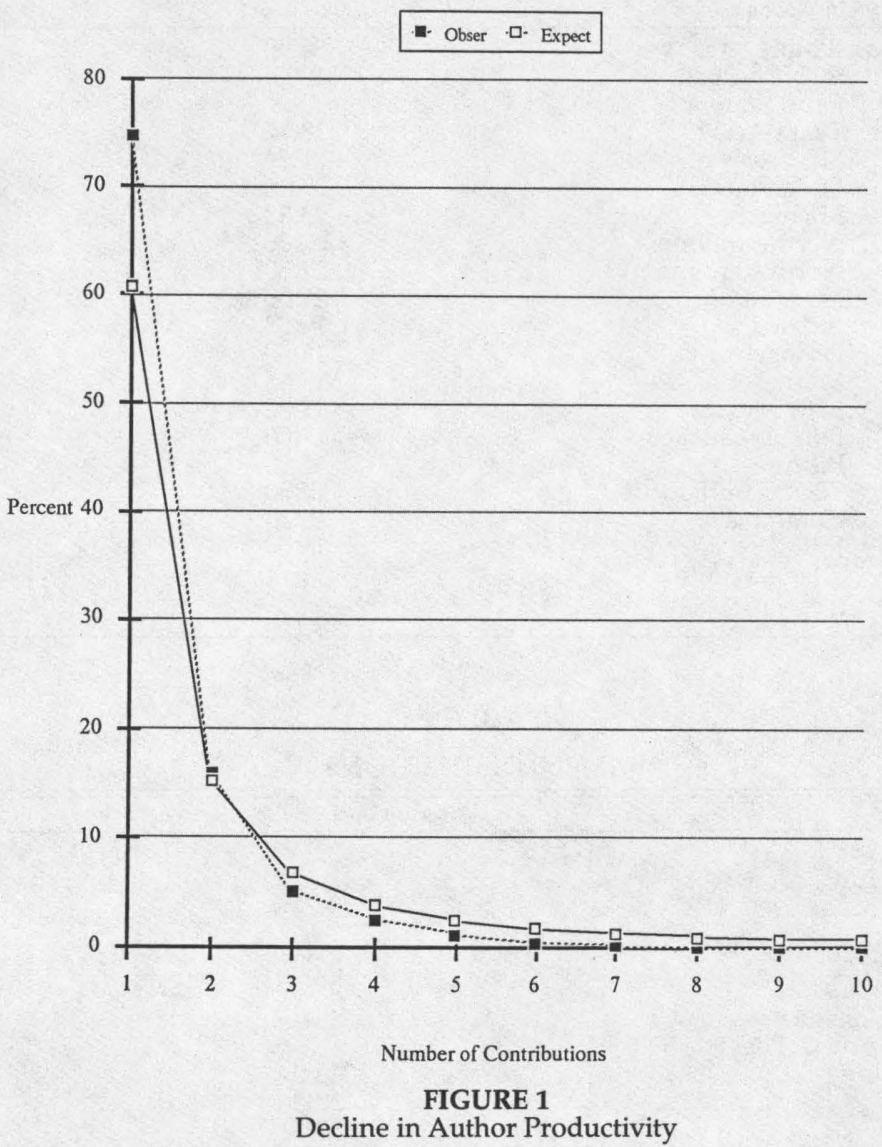

ability of a Type I error (that is, the chance of rejecting a true hypothesis) to .05 . One difficulty with the application of this formula revolves around the estimation of the values of $\sigma^{2}$ and $\delta^{2}$. This may be obviated by defining $\delta$ in terms of $\sigma$, so that $\sigma=$ $\delta$ and $\sigma^{2} / \delta^{2}=1$. This operation results in $\mathrm{n}$ $=(2.58+1.29)^{2}=15$ (after rounding upwards). Since $\sigma^{2}$ cannot be estimated, $\mathrm{Z}$ scores should be replaced with $t$ scores. One simple way to accomplish this is to multiply $\mathrm{n}$ by $($ error $\mathrm{df}+3) /($ error $\mathrm{df}+1)$, with error df being $\mathrm{n}-1$. Employing this yields a sample size of seventeen. The sample libraries are listed in table 4 .

The questionnaire asked three ques- tions relevant to the present study: do librarians at the institution have faculty or academic status? If there is a form of faculty or academic status, is publication of articles in journals of library and information science required for purposes of tenure or continuing status and if there is a form of faculty or academic status, is publication required for promotion? Table 5 presents results of the survey.

Because of what would have been small cell sizes, the data are not analyzed beyond the percentages shown. The following comments are offered on the results presented in table 5. First, we had not expected the sample group to so closely 
TABLE 3

MOST PRODUCTIVE INSTITUTIONS

\begin{tabular}{rlcr}
\hline \hline Rank & Institution & Total Credit & Per Capita \\
\hline 1 & Illinois & 88.00 & .693 \\
2 & SUNY-Albany & 40.66 & .667 \\
3 & Penn State & 29.8 & .266 \\
4 & Texas A\&M & 28.17 & .433 \\
5 & Northwestern & 27.50 & .267 \\
6 & Ohio State & 27.16 & .251 \\
7 & Michigan & 23.33 & .161 \\
8 & Northern Illinois & 22.66 & .462 \\
9 & North Carolina & 22.50 & .197 \\
10 & Iowa State & 21.50 & .448 \\
11 & Indiana & 19.83 & .182 \\
12 & Pennsylvania & 18.50 & .167 \\
13 & Minnesota & 17.83 & .177 \\
14 & New Mexico & 17.32 & .259 \\
15 & Illinois-Chicago & 17.00 & .233 \\
15 & Purdue & 17.00 & .395 \\
17 & SUNY-Buffalo & 15.50 & .170 \\
18 & Columbia & 15.33 & .102 \\
19 & LSU & 15.00 & .224 \\
20 & Georgia State & 14.74 & .409 \\
& & & .380 \\
\hline
\end{tabular}

TABLE 4

SAMPLE INSTITUTIONS

\begin{tabular}{lrr}
\hline \hline Institution & Total Credit & Per Capita \\
\hline Brooklyn College & 2.33 & .090 \\
Carnegie-Mellon Univ. & 12.32 & .440 \\
Georgia State & 13.74 & .382 \\
Georgia Tech & 7.66 & .156 \\
Indiana State Univ. & 8.00 & .267 \\
New York Univ. & 13.73 & .130 \\
Rancho Santiago College & 2.00 & .400 \\
(formerly Santa Ana College) & 2.00 & .286 \\
Sangamon State Univ. & 2.33 & .106 \\
Smith College & 6.91 & .072 \\
Univ. of Arizona & 3.00 & .052 \\
Univ. of Missouri & 8.00 & .320 \\
Univ. of Nevada-Reno & 1.00 & .045 \\
Univ. of Southern Maine & 5.00 & .091 \\
Univ. of Tennessee & 1.00 & .067 \\
Univ. of Tennessee-Chattanooga & 2.00 & .167 \\
Univ. of Wisconsin-Stout & 9.16 & .204 \\
Univ. of Wyoming & & .190 \\
& & \\
\hline
\end{tabular}

TABLE 5

COMPARISON OF REQUIREMENTS, TOP TWENTY, AND SAMPLE GROUP

\begin{tabular}{lcc}
\hline \hline Category & $\begin{array}{c}\% \\
\text { Top Twenty } \\
\text { N }=18\end{array}$ & $\begin{array}{c}\% \\
\text { Sample Group } \\
\text { N = 17 }\end{array}$ \\
\hline Faculty/Academic Status & 88.8 & 82.4 \\
Publication for Tenure $^{*}$ & 82.3 & 60 \\
Publication for Promotion & 88.2 & 64.3 \\
\hline
\end{tabular}

*Publication is either required or strongly encouraged for both promotion and tenure. 
match the top twenty in terms of faculty/academic status. It is possible that the sample is somewhat skewed. In any case, further investigation into the demographics of faculty/academic status may be called for. Secondly, table 5 does show a rather large difference between the two groups in terms of publication being required/encouraged for tenure and/or promotion.

\section{"There seems to be a disparity be- tween the rhetoric of the require- ments and the performance exhibited by librarians at these institutions."}

The publishing impetus is clearly present in the top twenty producers, considerably less so in the sample group. On the other hand, 60 percent of the sample group claims that publication is required/ encouraged. There seems to be a disparity between the rhetoric of the requirements and the performance exhibited by librarians at these institutions.

\section{CONCLUSION}

The publishing requirement in academic libraries quite clearly is not as widespread as may be commonly believed. The 384 institutions identified in this study as producing at least one contribution constitute only 18.3 percent of the 2,074 fouryear institutions of higher learning in this country. ${ }^{18}$ This suggests that academic librarians have a wide range of employment possibilities that do not require publication for continued employment.

On the other hand, "publication" may have different interpretations at different institutions. The journals investigated here are at the national level and most are refereed. Also, only articles are counted as publications here. It may be that at some institutions anything in print-book reviews, reports of meetings, news notes, etc. - is seen as publication suitable for meeting promotion and tenure requirements. If this is true, it probably represents a departure from the requirements of the teaching faculty at these institutions. It is not the purpose of the present paper to advocate or condemn faculty status for librarians, but the results of this study may stimulate further discussion of the definition of faculty status. There is no doubt that well-conceived, well-executed contributions to the library literature are useful and welcome. It is also difficult to dispute the fact that there are many demands on librarians' time. What may be needed in the future is rhetoric that more closely resembles reality and policy based on reasonable expectations of achievement.

\section{REFERENCES}

1. Emily Werrell and Laura Sullivan, "Faculty Status for Academic Librarians: A Review of the Literature," College \& Research Libraries 48:95-103 (Mar. 1987).

2. Kee DeBoer and Wendy Culotta, "The Academic Librarian and Faculty Status in the 1980s: A Survey of the Literature," College \& Research Libraries 48:215-23 (May 1987).

3. Ronald Rayman and Frank William Goudy, "Research and Publication Requirements in University Libraries," College \& Research Libraries 41:43-48 (Jan. 1980).

4. Ibid., p.45.

5. Ibid.

6. W. Bede Mitchell and L. Stanislava Swieszkowski, "Publication Requirements and Tenure Approval Rates: An Issue for Academic Librarians," College \& Research Libraries 46:249-55 (May 1985).

7. Robert Boice, Jordan M. Scepanski, and Wayne Wilson, "Librarians and Faculty Members: Coping with Pressures to Publish," College \& Research Libraries 48:494-503 (Nov. 1987).

8. Sylvia C. Krausse and Janice F. Sieburth, "Patterns of Authorship in Library Journals by Academic Librarians," Serials Librarian 9:127-38 (Spring 1985) and Paula D. Watson, "Production of Scholarly Articles by Academic Librarians and Library School Faculty," College \& Research Libraries 46:334-42 (July 1985).

9. Krausse and Sieburth, "Patterns of Authorship," p.128. 
10. Watson, "Production of Scholarly Articles," p.335.

11. David P. Kohl and Charles H. Davis, "Ratings of Journals by ARL Library Directors and Deans of Library and Information Science Schools," College E Research Libraries 46:40-47 (Jan. 1985).

12. Watson, "Production of Scholarly Articles," p.335.

13. Krausse and Sieburth, "Patterns of Authorship," p.130.

14. Watson, "Production of Scholarly Articles," p.336.

15. Alfred J. Lotka, "The Frequency Distribution of Scientific Productivity," Journal of the Washington Academy of Science, 16:317-23 (1926).

16. Russel C. Coile, "Lotka's Frequency Distribution of Scientific Productivity," Journal of the American Society for Information Science 28:366-70 (Nov. 1977).

17. Robert G. D. Steel and James H. Torrie, Principles and Procedures of Statistics: A Biometrical Approach, 2d ed. (New York: McGraw-Hill, 1980), p.118.

18. Chronicle Four-Year College Databook, 1987-88 (Moravia, N.Y.: Chronical Guidance Publications, Inc., 1987).

\section{APPENDIX A. JOURNALS EXAMINED}

Behavioral and Social Sciences Librarian

Bulletin of the American Society for Information Science

Cataloging and Classification Quarterly

Collection Building

Collection Management

College $\mathcal{E}$ Research Libraries

Database

Government Information Quarterly

Government Publications Review

Information Processing and Management

Journal of Academic Librarianship

Journal of Library Administration

Journal of Library History (now Libraries and Culture)

Journal of the American Society for Information Science

Library Acquisitions: Practice and Theory

Library and Archival Security

Library and Information Science Research

Library Hi-Tech

Library Journal

Library Quarterly

Library Resources E Technical Services

Library Trends

Microform Review

Notes

Online

Online Review

$R Q$

$R S R$ : Reference Services Review

The Reference Librarian

Research Strategies

Resource Sharing and Information Networks

Science and Technology Libraries

The Serials Librarian

Special Libraries Association, Geography and Map Bulletin

Technical Services Quarterly

Western Association of Map Librarians Information Bulletin 